\title{
Relationship between joint movement and mining subsidence
}

Gareth Swift

Abstract

The hazards associated with the possible collapse of old mine workings underlying an active landfill site in north-east England have been identified as a significant concern to both the regulatory authorities and to the landfill operator. A quantitative assessment of the hazards and their perceived risks to the integrity of the composite lining system in place beneath the landfill has been undertaken using a combination of field observation, established mine subsidence prediction tools and numerical modelling techniques. Field observations have identified the presence of extensive fissuring within the limestone underlying the site, however, it is difficult to assess the extent to which mining has contributed to the development of these features. In light of this, an influence function technique has been used to attempt to predict the degree of fracturing that could have been experienced at the surface due solely to mining, with the intention of illustrating whether the scale of movements on pre-existing joints could be attributed to mining subsidence. The results of this analysis have subsequently been used within a finite-difference numerical model to assess the effect that a fracture of the scale predicted would have on the composite lining system.

Introduction

It has long been recognised that the effects of ground movements associated with active and abandoned coal-fields can have important consequences for land use and construction activities (see, for example, Anon 1959; Wardell 1954; Whittaker and Reddish 1989) primarily due to the subsidence that may occur contemporaneously with mining (active subsidence) or residual movements taking place some period after the cessation of mining, normally within one or two years, but could be up to 5 years, depending on such factors as depth of working and geology (Whittaker and Reddish 1989). In the UK, coal has been extracted extensively by partial extract methods or by longwall extraction, which involves the almost complete extraction of the coal seam beneath the ground surface. Supporting pillars of coal are left between adjacent panels to provide roof support. In addition, temporary support is provided at the face and adjacent to roadways, which would subsequently be removed following the extraction of the coal. As a consequence of this, ground movements at the surface would occur approximately simultaneously with the advancing coal face. Importantly, from a surface development perspective, ground movements associated with longwall mining are in general, reasonably well understood, and the prediction of the magnitude and extent of expected ground movements can be made with some confidence. Complications to this observation do exist however, for example, the presence of faulting (see, for example, Donnelly 
2006), the interaction between coal seams worked at different levels, variations in the topography and dipping coal seams all may need to be taken into account when attempting to predict the magnitude and extent of surface subsidence and ground strains.

Although most ground movements associated with longwall mining tend to occur at the same time as coal extraction takes place, some residual movements may also occur. Bell and Donnelly (2006) observe that the magnitude of residual subsidence is proportional to the rate of subsidence of the surface and is related to the mechanical properties of the overburden strata. In general, residual movements tend to be $<10 \%$ of the maximum subsidence, although exceptions to this have been recorded (Bell 1999).

In addition, in the UK alternative types of mining were adopted. The most common, certainly during the eighteenth and nineteenth centuries, was the room and pillar form of mining, where galleries (rooms) were extended out into the seam from a shaft. As cross-galleries were developed so did a network of broadly square or rectangular pillars of unworked coal left behind as a form of 'permanent' roof support for the workings. Further extraction from these pillars (known as 'robbing') would occur on retreat towards the shaft, and in some cases, the pillars might be completely removed leading to roof collapse. Depending upon the depth of overburden and the presence of competent horizons, the consequences for the surface environment and surface developments of such mine workings may be significant if the overburden thickness is small or the overlying strata is weak. Subsidence associated with these types of workings depends largely upon the mechanisms of failure within the workings but also the overburden thickness and the mechanical properties of the overburden. For example, a subsidence trough may develop if pillar, roof or floor failure occurs within the workings over a wide area (loads transferred from adjacent pillars may lead to progressive failure of pillars as pillar strength is exceeded, for instance), or ground movements might be localised as roof collapse occurs above open galleries (sinkhole formation). Typical forms of subsidence and relevant terms are shown in Fig. 1.

The area considered as a case study within this paper surrounds the Houghton Quarry and landfill site, located north of Houghton-le-Spring, approximately $8 \mathrm{~km}$ south-west of Sunderland city centre and $10 \mathrm{~km}$ north-east of Durham (Fig. 2). The quarry has been worked since 1847 with extraction completed by 1996. This location has been extensively undermined at different elevations and at different times and this paper considers the significance of this in the context of ground stability.

The potential physical and environmental impacts associated with the possible collapse of old coal workings underlying surface structures, rising mine water and the reactivation of geological faults are a concern to all relevant stakeholders associated with surface developments. One of the primary concerns here could be the potential instability of lining systems installed at Houghton Quarry landfill site arising from subsidence 
movements along (shear) and across (translational) pre-existing fissures and faults within the Magnesian Limestones of the Raisby Formation. It is postulated that past subsidence movements may be related to undermining of the site through either longwall total extraction methods or room and pillar partial extraction methods. Since most ground movements associated with longwall mining occur at the same time as extraction takes place, it is considered that subsidence due to longwall mining in this case will be largely complete, in the context of this study. Those seams that have been partially extracted will however be considered as these present a greater risk in terms of residual subsidence after mining has been completed. The degree to which these workings affect the stability of the overlying surface forms the basis of this investigation. Determining the effect of the potential ground movements on the integrity of existing clay and geomembrane liner provides an additional element to the investigation, and a tentative attempt has been made to quantify these effects through numerical modelling.

Extensive work has already been undertaken by Young and Culshaw (2001), Young and Lawrence (2002) and Wigham (2000), amongst others, examining the geology of the area with particular reference to the nature and distribution of fissuring within the limestone. Figure 3 shows the geological succession in the Houghton le Spring area. A number of mechanisms were proposed by Young and Culshaw (2001) for the fissuring. These include:

- Near-surface mass movement (landslides and flows);

- Tectonic stresses (faulting, jointing and folding) and;

- Mining (subsidence, fault reactivation, etc.).

A number of other mechanisms, such as cambering and dissolution of the limestone, were also proposed by these authors, but these were discounted as unlikely to produce the scale of fissuring in evidence at Houghton. The authors, as well as other researchers (for example, Wigham 2000), believed that renewed or continuing subsidence of abandoned coal mine workings, or reactivation of faults ('reactivation' in this context refers to recent movements associated with previously inactive faults), may be a contributory factor in the formation of the surface fissures observed in this area. Furthermore, rising minewater levels within the abandoned coal workings may also be a contributory factor for renewed subsidence or fault reactivation (Young and Culshaw 2001).

In terms of mining, the coal seams identified beneath the Houghton-le-Spring Landfill are presented in Table 1, along with the elevation and the seam thickness. The coal seams and the extent of workings were identified from geological maps (1:50,000 scale Sheet 21 (Sunderland) and Smith 1994) and coal abandonment plans held by the Coal Authority. It should be noted that the base of the quarry is at $68 \mathrm{~m}$ above ordnance datum. 
The mine abandonment plans indicate that workings beneath the quarry were from the Houghton Colliery which was originally sunk to the level of the Hutton seam between 1,823 and 1,827 , extended in the 1920 s1930s to take coal from the Busty and Harvey seams. The colliery was abandoned in 1981.

In addition to the seams identified in Table 1, two other seams have also been worked in this area; the Busty (bottom and top; mined as one unit) and the Harvey. Abandonment plans indicate that these seams were worked by longwall mining directly beneath the quarry up to the 1960s, and they have therefore not been considered within the stability analyses, as it is likely that no voids remain in these seams and that subsidence is therefore complete. It is possible that there may be some residual movements associated with these workings; however, it is assumed here that the shallower workings are more likely to have a greater influence on the surface and near-surface stability. In addition, it should be recognised that this is a complex multi-seam mining situation and it is likely that the influence of the older, shallower workings on the surface environment may well have been modified by the effects of the underlying, more recent workings in the Busty and Harvey seams. The analysis presented here must be considered as a step in understanding the influence of mining on pre-existing geological features, such as faults and fissures, and that subsidence prediction in complex sequences such as those found in this locality is an area of ongoing research.

The working methods adopted in the remaining seams vary. For the most part longwall methods have been used; however, in some areas and in some seams partial extraction methods were also adopted, principally the room and pillar method. Workings shallower than the Ryhope Little Seam are unlikely to exist. Indeed, this seam itself does not appear to have been worked in the area, probably due to it being very thin. Abandonment plans record no workings shallower than the Five Quarter Seam, and the assumption was made that the shallowest workings beneath the quarry lie within the Five Quarter Seam.

Site observations

Observations within the quarry focussed on the nature and presence of fissures, whether joints or faults in the face and floor of the quarry. It was evident that a greater degree of fissuring of the Limestone had taken place along the north face of the quarry. Jointing of the limestone in the southern face was less frequent, though there were a few east-west trending, closed joints in the east face of the quarry. Although joints were observed in both areas, it was difficult to ascertain their presence, persistence, or condition in the quarry floor due to ongoing landfilling operations. 
Further observations made from the north rim of the quarry revealed a large open fissure in the limestone, trending approximately west-south-west to east-north-east. This fissure had an approximate width at the surface of in excess of $0.3 \mathrm{~m}$ and showed extensive weathering and erosion including large blocks of collapsed limestone.

The visit extended to the south-east of the quarry and included the A690 road and the 'Old Cemetery' where further geological observations were made. A repaired stretch of the $\mathrm{A690}$ was clearly visible, as was the presence of further cracking within the road surface approximately $5 \mathrm{~m}$ south of the repair. This observation was also reported by Donnelly (1998) and Wigham (2000). Extrapolating this cracking with previous observations within the quarry it was clear that the trend was similar and they were aligned with similar trending fissures within the rocks exposed in the east and west walls of the cutting, i.e. approximately west-south-west to east-north-east. It has been highlighted that these cracks lie along the line of a recognised geological fault; the southern branch of which passes to the south of the landfill site (BGS Sheet 21 [Sunderland]). The observed features within the road surface could represent 'reflective cracking' caused by deflection of the flexible road surface above a pre-existing fissure or in this case a fault, which has then subsequently dilated (Anon 2000). Over time, and with the passage of vehicular traffic on the road surface, the underlying fissure migrates to the surface. This is a phenomenon that is common in highways throughout the UK and elsewhere.

A number of the fissures in the western side of the cutting were observed to continue into the slope. An open fissure with an aperture of about $0.3 \mathrm{~m}$ was observed at the rear of this slope (Fig. 4). This fissure is in the form of an elongated sinkhole, where the material bounded by the two sides of the fissure has collapsed vertically into the void. Further sinkhole features were observed along the line of this fissure.

Numerous fissures, closed and open, were observed in either side of the cutting of the A690. Some of these had formed gullies, with a fractured zone in excess of $2 \mathrm{~m}$ in width (Fig. 5). These gullies were not open for their entire width, but rather, contained broken limestone blocks that either bridge the void or partly fill the fissure. The open fissure width in this figure was measured to be between 0.3 and $0.5 \mathrm{~m}$.

The Old Cemetery lies between the A690 and Hillside Farm. Large exposures of the Magnesian Limestone of the Raisby Formation were clearly seen, representing the face of a small quarry/cutting; the cemetery itself is located on what was an old quarry floor.

Again the fissures were aligned with those observed within the quarry and in the adjacent road cutting, with one wide open fissure taking prominence in the north-west corner of the site (Fig. 6). The width of this 
fissure was approximately $1 \mathrm{~m}$. Parallel fissures were observed in the face of the cutting, however, none of these were open.

Correlating the observations made of the fissuring within the quarry side walls and those made outside the quarry confirm that a combination of stress relief due to excavation and depth to bed rock determine the aperture size where the fissures are visible at outcrop. In other words, in the base of the quarry, any fissures will be horizontally confined and are therefore unlikely to open to the magnitude of the examples shown in Figs. 4 and 5. These observations can be considered in the context of work undertaken by Donnelly et al. (2010) in the South Wales coalfield, where the authors considered the evolution of fissures and mining subsidence. Although the mechanisms are likely to be different, the descriptive terminology used by Donnelly can be applied here. There is evidence of joint dilation in this area (Fig. 5) and what might be referred to as advanced fissuring (Donnelly et al. 2010) as linear features develop due to superficial deposits bridging underlying fissures (Fig. 3). Furthermore, it is the authors opinion that the width of the fissures indicated in Figs. 3, 4 and 5 are likely due to dilation and extension relating to a combination of stress relief and undermining, though this has been exacerbated in some cases (for example, Fig. 4) by erosion of the side walls and subsequent collapse. It should be noted that the causes of stress relief in this context do not relate to deglaciation, as they might in the areas in which Donnelly et al. (Op Cit) studied, but rather to engineering works, such as the formation of the road cutting and excavation of the quarry (both Houghton and the Old Cemetery), in this case, the issue relates more to a reduction in horizontal confinement.

The observations made relate to the nature of the fissuring within the Magnesian limestone. However, it is understood that part of the operating landfill lies on the Yellow Basal Sands of Permian age. This strata is described as poorly cemented sands by the BGS, that have been faulted and gently folded. It is envisaged that the magnitude of open fissuring within the Yellow Sands will be significantly less than that observed within the limestone.

Assessment of ground movement

Ground movement due to mining

An assessment of the ground movement due to mining was conducted using the Subsidence with Influence Function Techniques (SWIFT) computer package developed by the University of Nottingham (Ren et al. 1987). This uses the stochastic influence function method as a basis for calculation of subsidence and strain 
associated with underground mining. The basic principle of the method is the application of the law of superposition to determine the overall influence of an extraction area treated in infinitesimal parts (Sheorey et al. 2000; Dunham et al. 1995; Reddish et al. 1994; Ren et al. 1987).

There are numerous methods available to predict mining subsidence, ranging from theoretical methods based on continuum mechanics, empirical and semi-empirical methods, such as profile and influence functions, and numerical methods using finite element or finite difference techniques. The Subsidence Engineers Handbook (SEH) (National Coal Board 1975) has been used extensively to predict subsidence, displacements and strains associated with some UK longwall mining cases, but has been less successful in relation to non-rectangular workings (Whittaker and Reddish 1989). Traditionally, the most appropriate methods for dealing with irregular shaped workings involve either influence function or zone area methods. More detail regarding the analysis conducted here is presented in Ren et al. (1987).

The analysis using the influence function technique gives the total subsidence at the surface due to mining, as well as the surface strain and surface displacement vectors. Ground strain is the resultant of extension and compression of the surface as a result of subsidence and represents the ratio of the change in ground length to the original ground length, and therefore can be positive (extension) or negative (compression).

\section{Description of the SWIFT analysis}

Five seams were examined in detail: Five Quarter, Main, Maudlin, Low Main and Hutton, as these all had areas of room and pillar workings underlying the quarry or immediately adjacent to the quarry. The shallowest of these workings was in the Five Quarter seam at a depth of $175 \mathrm{~m}$ below the base of the quarry. The Main and Maudlin seams were at depths of 242 and $261 \mathrm{~m}$, respectively. The Low Main and Hutton seams were 282 and $310 \mathrm{~m}$ below the base of the quarry. Seam thickness varied from seam to seam. The thickest was the Hutton at $2.3 \mathrm{~m}$, followed by the Main at $1.9 \mathrm{~m}$, the Maudlin at $1.5 \mathrm{~m}$, the Low Main at $1.4 \mathrm{~m}$ and the Five Quarter which was only $1 \mathrm{~m}$ thick. In all cases, an extraction ratio of 0.6 or $60 \%$ has been assumed. This is considered to be a conservative assumption based on the abandonment plan data and knowledge of room and pillar working; in general, room and pillar mining commonly extracts between 50 and $70 \%$ of coal leaving the remainder as roof support in the form of pillars (Whittaker and Reddish 1989; Kratzsch 1983; Statham 1951). All models were run on a 25-m grid through the area of interest. 
Results of the SWIFT analysis

As discussed previously, the complex interaction between the deeper, more recent longwall workings and the older, shallower workings is outside the scope of this analysis. The analysis has assumed for simplicity that the sequence of coal extraction was completed in the shallower seams first. Clearly, the situation is more complex than this; the extraction within the Hutton seam was completed prior to the start of extraction from overlying seams and workings within the Maudlin seam appear to have completed before those in the Main seam, beneath the quarry. However, the intention of the analysis presented herein is to demonstrate that the scale of fissuring observed at the surface in this area could be related to ground movements caused by historical mining activities.

Initially, the modelling examined the shallowest seam only, the Five Quarter, to establish the subsidence, strain and displacement patterns at the surface. Subsequent models were developed in stages of increasing complexity, incorporating the mining details from deeper seams. Each stage was examined to assess the degree of surface movements, whether horizontal or vertical.

The results of the final model incorporating all the relevant workings in all the seams beneath the Houghton Quarry are reproduced in Figs. 6-8. The maximum surface subsidence has been predicted to be $0.85 \mathrm{~m}$. The surface strain vectors (Figs. 7, 8) and the surface displacement vectors (Fig. 9) both indicate zones of extension between the subsidence troughs shown in Fig. 6 .

\section{Discussion}

From the figures, it is difficult to determine the effect that these movements might have on surface fissures. Likely zones of extension can be clearly identified, however quantifying the likely movements across existing fissures would be more useful; that is, it is assumed that the fissures pre-date mining activity and it is the post-mining movements that are to be examined. With this in mind, the displacement data were used to predict the movement across assumed fissures running north-south and east-west across the Houghton Quarry area. The displacement data was used to provide a prediction of absolute movements across the fissures. Essentially, the raw displacement data used to derive the earlier displacement vector plots were re-calculated to determine the horizontal displacement at a given offset. A spacing between fissures of $25 \mathrm{~m}$ was assumed and the displacement values were therefore corrected for a $12.5-\mathrm{m}$ off-set.

The results of this analysis are presented in Fig. 10 for horizontal displacements across east-west trending fissures, and Fig. 11 for horizontal displacements across north-south trending fissures. 
In both figures, the lighter shading represents zones of compression, whereas the darker areas are zones of tension. In Fig. 10, these are seen to have a linear trend with a maximum extension of $0.06 \mathrm{~m}$. In the case of north-south aligned fissures, the maximum extension is only $0.02 \mathrm{~m}$ (Fig. 11).

Although typical values of fissure spacing have been used $(25 \mathrm{~m})$, the effect of increasing or decreasing the spacing has also been examined. In this case, 16 and $50 \mathrm{~m}$ have been used as lower and upper bound values, respectively.

These models (not presented here) indicated that in the case of east-west aligned fissures, the maximum displacement would be $0.05 \mathrm{~m}$ for the $16-\mathrm{m}$ case and $0.06 \mathrm{~m}$ for the $50-\mathrm{m}$ case. For north-south aligned fissures, the maximum displacement would be 0.014 and $0.03 \mathrm{~m}$, respectively.

These results show that the inferred fissure aperture does not significantly change with increased or reduced spacing.

The results also indicate that the predicted magnitude of movement across pre-existing fissures is less than that observed from exposures in the field. This is likely due to a combination of factors, such as the contribution of other causal mechanisms (e.g., near-surface engineering activities, erosion, possible groundwater rebound, etc.) as well as simplifications within the analysis conducted. However, what the analysis attempts to quantify are the magnitude dilation associated with existing fissures due to mining activities within the identified seams beneath this area.

Implications of groundwater rebound

Stability of mine workings

The effects of groundwater rebound on this specific site are difficult to quantify. However, there are essentially two issues; the effects on the stability of the mine workings and the effects on the stability of faults and fissures. The effect of water on mine excavations can be argued to have both beneficial and detrimental effects, complicated further by the issues relating to weathering and time. Ultimately, it is a balance of these that determines whether flooding of old workings will have positive or negative implications for ground stability, e.g., subsidence or 'upsidence'. 
In relation to longwall workings, groundwater rebound will have a limited effect. Work undertaken by Pottgens illustrates the potential for recovery of groundwater levels inducing heave or vertical uplift ('upsidence') at the surface caused by an increase in pore pressures in the disturbed strata above the longwall panel (Bekendam and Pottgens 1995; Pottgens 2000).

\section{Room and pillar workings}

In collapsed room and pillar workings, the presence of water, as with the longwall workings, may lead to further subsidence of the disturbed rock and since these may have collapsed more recently, it is possible that further collapse may ensue as clay or silt fines are washed out. This may cause further surface subsidence to affect the surface environment.

In intact workings it is necessary to understand the effects of water on rock strength. There are three main issues:

1. Laboratory rock sample strength reduces significantly from an oven dry state to complete saturation with water. A rock may easily lose up to $50 \%$ of its laboratory strength as it goes from being completely dry to fully saturated. However, it should be borne in mind that in situ rocks are never completely dry, thus the change in strength will be much reduced in practice;

2. Rooms and pillars within mine workings constitute structures, and the rock from which these structures are made contain joints, bedding planes and mining induced fractures. When dry these structures have frictional properties that help hold them together. The presence of water, under pressure could reduce the available shear strength (Jaeger et al. 2007). Rock mass classification techniques acknowledge the deleterious effects of water and make significant strength reductions to rock mass properties to reflect the detrimental effects of the presence of water;

3. Certain rock types are particularly prone to strength reductions due to the presence of water due to the chemical or physical reaction between constituent parts, such as clay minerals (kaolinite, illite and montmorillinite) and the water. The swelling properties of some clay minerals in the presence of water should also be recognised. Where rocks containing such minerals form part of the roof, pillars or floor of the excavation, the potential for weathering, weakening and hence failure is high.

Groundwater in the mine, if completely flooded, can provide a buoyant force that may help support the mine roof (Goetz et al. 1994). Also, pillars may retain their strength because the lack of oxygen in the water-filled mine prevents the chemical breakdown of the coal and any timber supports. However, rising groundwater can also remove soluble salts from the pillars, resulting in a decrease in strength. 
Therefore, it is the changes in the water level within the mine that may increase the possibility of pillar failure, for example, draining a flooded mine or flooding a dry mine. Such changes in equilibrium initiated by flooding can contribute to the initiation of subsidence long after the mine ceases to operate, and therefore could lead to further residual or ongoing subsidence.

Implications of groundwater rebound: stability of faults and fissures

The possibility of fault or fissure reactivation as a result of groundwater rebound must also be considered, (Donnelly 1994; Donnelly et al. 2008).

Groundwater rebound may increase the pore-fluid pressure within the fault, resulting in a reduction in the shear strength. This could possibly act against the normal stress acting across the fault, possibly leading to reactivation. Yu et al. (2007) consider this in detail demonstrating that as groundwater levels rise, porewater pressure changes are expected, resulting in decrease of the apparent coefficient of friction. The authors considered this in relation to the Houghton-le-Spring fault, suggesting that reactivation of this fault was due to groundwater rebound and not due to mining subsidence, however there is no direct evidence to support this observation.

The presence of soft fill material, such as clay gouge, may also drastically reduce the shear strength along discontinuities and may therefore increase the likelihood of slip by reducing the degree of contact between adjacent fault surfaces. However, in the case of the observed fissures, this is unlikely as insignificant fill material was observed to be present on the contact surfaces at Houghton-le-Spring.

Groundwater rebound in relation to possible causative methods for fault reactivation and subsidence still remains somewhat speculative, with little supportive evidence.

The surface fissures observed in the Houghton area could have been formed by active undermining, and therefore may have been present for a number of years since the cessation of mining. Young and Culshaw (2001) consider it to be unlikely that such fissures have lain dormant beneath the site since mining ceased, before suddenly appearing at the surface as the overlying soil cover collapses into the void. However, Donnelly and Rees (2001) and Donnelly et al. (2010) provide evidence for this mechanism, albeit in a different part of the UK. Further, Young and Culshaw (2001) observe that the fissures display a clear spatial relationship with existing faults, namely the Seaham to the north of the quarry, and the Houghton Cut to the south, whereas if the fissures were related to mining then it would be expected that they would exhibit a distribution more closely related to the configuration of the underlying mine workings. 
Young and Lawrence (2002) state that there is clear evidence of recent, and continuing, active movement associated with these fissures and concludes that fissure formation and resultant surface collapse is still active and may be expected to continue. There is no evidence to suggest that this is not the case, however, the fissures observed by the present author show both a horizontal component and a vertical component; the latter has been estimated at approximately $0.3 \mathrm{~m}$.

In general, the impact of groundwater rebound in mining areas remains an area of significant uncertainty. The influence of mining activities on fissuring and fault reactivation is also unclear, and the effects of groundwater rebound on ground stability and the stability of faults is an area of ongoing research.

\section{Crown hole development}

From the mining information examined, it is extremely unlikely that a localised roof failure within any of the workings leading to a collapse of the immediate overburden will propagate through the coal measures strata to the base of the landfill. Conservative estimates of 10 or 11 times the extraction height suggest that the sinkhole would bulk a significant distance below the level of the quarry. The threat of ground failure as a result of mine workings at depths in excess of $50 \mathrm{~m}$ is minimal. All workings beneath Houghton Quarry are in excess of $140 \mathrm{~m}$ below the base, and therefore there is a negligible chance of crown holes reaching the base of the quarry.

Numerical analysis

Introduction

A brief investigation has been carried out to assess the performance of a full composite lining system at an existing waste management site, using the finite difference numerical modelling code, Fast Lagrangian Analysis of Continua or FLAC (Itasca 1995). The model developed incorporates a simple five layer system: limestone bedrock, engineered fill, clay liner, geomembrane and a sand cover soil. The overlying waste material was simulated as a constant load on the upper boundary of the model, assuming a maximum depth of waste of $30 \mathrm{~m}$.

The properties used in the model were derived from published data (Jones and Dixon 2003; Dixon and Jones 2003) and are considered representative of the materials used at Houghton-le-Spring, and are presented in Table 2. 
Modelling methodology

The objective of the modelling was to simulate the response of a lining system to an existing open fissure at the base of the quarry beneath the composite lining system. Since the depth of the limestone does not affect the analysis, it was set at an arbitrary model thickness of $7 \mathrm{~m}$. Above the bedrock is a $1 \mathrm{~m}$ thick layer of engineered fill, a $1 \mathrm{mthickclaylineranda2mmthickgeomembraneabove} \mathrm{the} \mathrm{clay.} \mathrm{On} \mathrm{site,} \mathrm{the}$ geomembrane is overlain by a geo-textile and gravel leachate drainage system, but for simplicity, this was not incorporated within the model. Instead a $1 \mathrm{~m}$ thick layer of sand was simulated and a load equivalent to $30 \mathrm{~m}$ of waste was applied to the sand. A schematic of the model layout is given in Fig. 12.

The initial stage of the modelling is to define a mesh. This was done with $0.1 \mathrm{~m} 2$ elements defining an area $10 \mathrm{~m} 910 \mathrm{~m}$. Stresses were allowed to equalise within the model after the application of the vertical pressure on the upper boundary, representing the overlying waste $(350 \mathrm{kPa})$. A vertical fracture was then defined in the limestone bedrock and the model was allowed to run.

The results of the SWIFT analysis, summarised earlier, indicated that the maximum fissure width would be of the order of $0.06 \mathrm{~m}$ or $60 \mathrm{~mm}$. A width of $100 \mathrm{~mm}$ was used for the FLAC simulation, which is nearly twice the anticipated fissure opening. The geometry of the grid and the fissure are shown in Fig. 13. The model was then run until displacements had stabilised and equilibrium reached.

Results of FLAC analysis

The results of the initial numerical modelling are shown in Figs. 14 and 15; the maximum displacement is around $0.05 \mathrm{~mm}$. Figure 14 shows the shear strain contours in the material surrounding the fissure. The scale of movements are very slight; the contour interval is $0.05 \mathrm{~mm} / \mathrm{m}$. Some shear strain can be seen in the sand overlying the geo-membrane but again the strains are extremely small.

Figure 15 shows vertical stress contours in the material surrounding the open fissure. A stress bulb above the fissure can clearly be seen, with small areas of relatively high stresses in the sidewalls of the fissure, indicating a maximum of approximately $300 \mathrm{kPa}$ in the sidewalls and $525 \mathrm{kPa}$ above the fissure opening. Stress levels in the engineered fill above the fissure decay rapidly to approximately $400 \mathrm{kPa}$ within $0.75 \mathrm{~m}$ and stresses of around $400 \mathrm{kPa}$ are predicted in the clay liner.

Two further models were developed in order to assess the sensitivity of the model to variations in the thickness of the engineered fill lying between the limestone and the clay liner. In the initial analysis it was assumed that the fill would be placed with a thickness of $1 \mathrm{~m}$, which corresponds to the mean thickness 
value for Cell 1. However, the thickness of engineered fill varies from $0.2 \mathrm{~m}$ to in excess of $2 \mathrm{~m}$, and these values were used in the analysis as the two extremes.

The 0.2-m model shows that although stresses are generated within the engineered fill, they do not propagate into the overlying clay liner, possibly due to differences in stiffness of the two materials. The stress bulb generated above the 0.1-m-wide fissure extends into the engineered fill, but instead of extending into the clay, spreads laterally as it approaches the boundary with the clay liner. Maximum stresses in the clay liner are again around $400 \mathrm{kPa}$, which indicates that $0.2 \mathrm{~m}$ of engineered fill is sufficient to ensure no additional stresses in the clay liner.

The 2-m model shows a similar pattern of stress distribution in that stress decay occurs within the engineered fill above the fissure and stresses have attained background levels within $1.5 \mathrm{~m}$ of the limestone.

In the context of the integrity of the lining system, the models predict that the lining will not be compromised due to the presence of a 0.1-m-wide fissure beneath the system.

Summary and conclusions

An assessment has been carried out of the likely effect of ground movements due to mining on the lining system at Houghton-le-Spring Landfill. This has taken the form of a review of the available information, assessment of likely ground movement due to mining and the likely effects of this movement on the lining system.

It is clear that fissuring is common within the Magnesian Limestone in the Houghton-le-Spring area, and beyond. The causal mechanisms are, however, not possible to postulate with any certainty, though it seems likely that past mining has had an influence; the degree of that influence is difficult to quantify.

Numerical analysis using SWIFT has been carried out to assess the likely ground movements due to mining. This has used past mining data and information to provide contours of surface subsidence above the extracted seams, and to predict surface strains and displacements in these areas. The development of these models has been documented, with results taken and analysed from each stage. The final stage represents a composite model of all the partially extracted seams beneath the quarry. This study has provided an analysis of the mining and geological data to predict the potential width of fissures, assuming that mining was the principal source of ground movements in this area. The width of these fissures has 
been predicted for the quarry base to be a maximum of $60 \mathrm{~mm}$. Observed fissures in the region have apertures in excess of $60 \mathrm{~mm}$ and this discrepancy might be explained through the simplified analytical model used to predict fissure aperture due to mining or in the fact that the fissures have been subject to additional movements not associated with past mining activities, such as groundwater rebound, although this remains somewhat speculative for this area.

The numerical modelling code, FLAC, has also been applied to the geological model. A simple model has been proposed to illustrate the mechanisms of failure should a fissure $100 \mathrm{~mm}$ wide develop within the Magnesian Limestone underlying the site. The model indicates that the presence of only $0.2 \mathrm{~m}$ of engineered fill is sufficient to prevent the fissure opening developing excessive stress within the lining system.

In summary, the SWIFT analysis has indicated that the maximum fissure opening due to mining at the quarry base level is predicted to be $60 \mathrm{~mm}$. A conservative fissure width of $100 \mathrm{~mm}$ has been simulated in the FLAC modelling, and even with this order of fissuring, it is considered that failure of the lining system will not occur.

\section{Acknowledgments}

The author wishes to gratefully acknowledge the financial and technical support afforded by Golder Associates and the contributions made by the late Dr David Reddish to the original text of this paper. In addition, the author would like to express his gratitude to the anonymous reviewers for the helpful comments on this paper.

\section{References}

Anon (1959) Report on mining subsidence. Institution of Civil Engineers, London

Anon (2000) Report on the proposal by biffa waste services to deposit special (toxic) waste in houghton quarry landfill site. Residents against toxic site

Bekendam RF, Pottgens JJE (1995) Ground movements over the coal mines of southern Limburg, The Netherlands, and their relation to rising mine waters. In: Land Subsidence: Proceedings of the Fifth International Symposium on Land Subsidence, The Hague, October 1995, IAHS Publ. No. 234, pp 3-12 
Bell FG (1999) Geological hazards: their assessment, avoidance and mitigation. Spon Press, New York Dixon N, Jones DRV (2003) Stability of landfill lining systems: guidance, environment agency research and development project P1-385, Report 2

Donnelly LJ (1994) Predicting the reactivation of geological faults and rock mass discontinuities during mineral exploitation, mining subsidence and geotechnical engineering. PhD Thesis, University of Nottingham

Donnelly LJ (1998) Fault reactivation and ground deformation investigation, Easington colliery, County Durham. British Geological Survey Technical Report WN/98/9

Donnelly LJ (2006) A review of coal mining induced fault reactivation in Great Britain. Q J Eng Geol Hydrogeol 39:5-50

Donnelly LJ, Rees J (2001) Tectonic and mining-induced fault reactivation around Barlaston on the Midlands Microcraton. Q J Eng Geol Hydrogeol 34(2):195-214

Donnelly LJ, Culshaw MG, Bell FG (2008) Longwall mining-induced fault reactivation and delayed subsidence ground movement in British coalfields. Q J Eng Geol Hydrogeol 41(3):301-314

Donnelly LJ, Siddle HJ, Northmore KN (2010) The origin of fault scarps and fissures on moorland plateaux and in the vicinity of landslides, in the South Wales Coalfield, UK. In: Proc. $11^{\text {th }}$ IAEG Congress, Auckland, New Zealand

Dunham RK, Reddish DJ, Yao XL (1995) PC-Based computer package for mining subsidence prediction. Coal International pp 189-192

Goetz D, Roussel V, Tincelin E (1994) Cave-ins linked to mine flooding. 5th International Mine Water Congress, Nottingham, UK, pp 29-42

ITASCA (1995) Fast Lagrangian analysis of continua (FLAC). Version 3.3, Itasca Consulting Group, Minneapolis Jaeger J, Cooke NG, Zimmerman R (2007) Fundamentals of rock mechanics, 4th edn. Wiley, New York 
Jones DRV, Dixon N (2003) Stability of landfill lining systems: literature review, environment agency research and development project P1-385. Report 1:219

Kratzsch H (1983) Mining subsidence engineering. Springer, Berlin National Coal Board (1975) Subsidence engineers' handbook. NCB Publications, Hobart House

Pottgens JJE (2000) Personal Communication

Reddish DJ, Yao XL, Dunham RK (1994) Risk assessment of structural damage due to mining subsidence-an integrated approach. In: Risk assessment in the extractive industries. Camborne School of Mines, University of Exeter

Ren G, Reddish DJ, Whittaker BN (1987) Computerised subsidence and displacement prediction using influence function methods. In: 7th Int. Conf. ground Control in Mining. West Virginia University, USA

Sheorey PR, Loui JP, Singh KB, Singh SK (2000) Ground subsidence observations and a modified influence function method for complete subsidence prediction. Int J Rock Mech Min Sci 37:801-818

Smith BD (1994) Geology of the country around Sunderland. Memoir of the British Geological Survey Sheet 21 (England and Wales)

Statham I (1951) Coal mining. English Universities Press, London

Tomlinson MJ (2001) Foundation design and construction, 7th edn. Prentice Hall, Englewood Cliffs

Wardell K (1954) Some observations on the relationship between time and mining subsidence. Transactions of the Institution of Mining Engineers, 113: 471-483 \& 799-814

Whittaker BN, Reddish DJ (1989) Subsidence: occurrence, prediction and control. Elsevier, Amsterdam

Wigham D (2000) The occurrence of mining induced open fissures and shear walls in the Permian limestones of County Durham. Conference 2000: The legacy of mineral extraction. Institution of Mining and Metallurgy and North of England Institute of Mining and Mechanical Engineers, 18th-19th May 2000, Newcastle upon Tyne, pp 71-82 
Young B, Culshaw MG (2001) Fissuring and related ground movements in the magnesian limestone and coal measures of the Houghton-le-Spring area, City of Sunderland: BGS Onshore Series Technical Report WA/01/04

Young B, Lawrence DJD (2002) Recent fissuring in the magnesian limestone at Houghton-le-Spring, City of Sunderland: BGS Survey Research Report RR/02/03

Yu MH, Jefferson I, Culshaw MG (2007) Fault reactivation, an example of environmental impacts of groundwater rising on urban area due to previous mining activities. In Proc. of the $11^{\text {th }}$ Congress of the ISRM, Lisbon, Portugal, 9-13 July 2007 


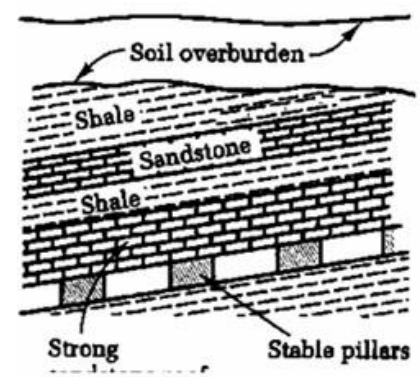

(a)

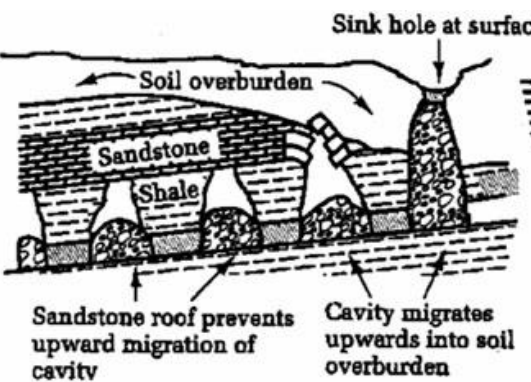

(b)

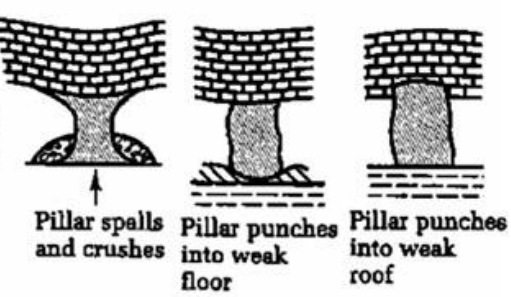

(c)

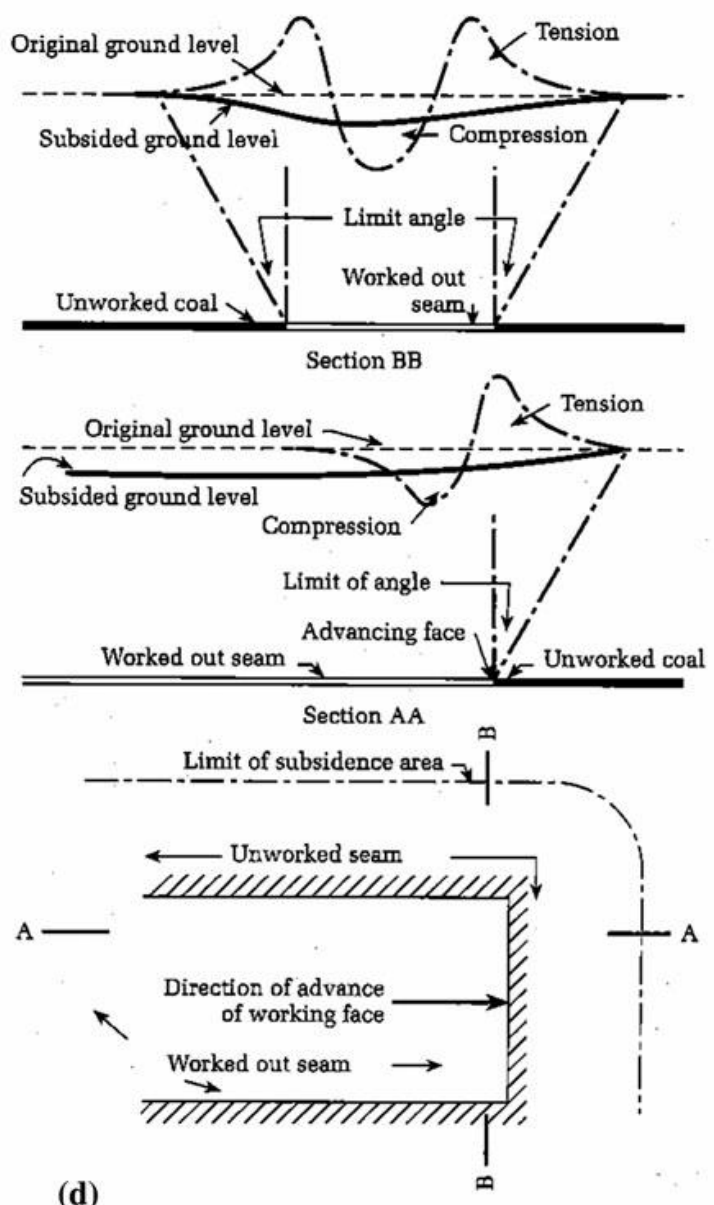

Fig. 1 Forms of ground movement associated with coal mine workings (not to scale): a stable room and pillar workings; b unstable room and pillar workings due to weak shale roof; c unstable room and pillar workings due to pillar failure; $d$ form of ground subsidence given by longwall working (Tomlinson 2001) 


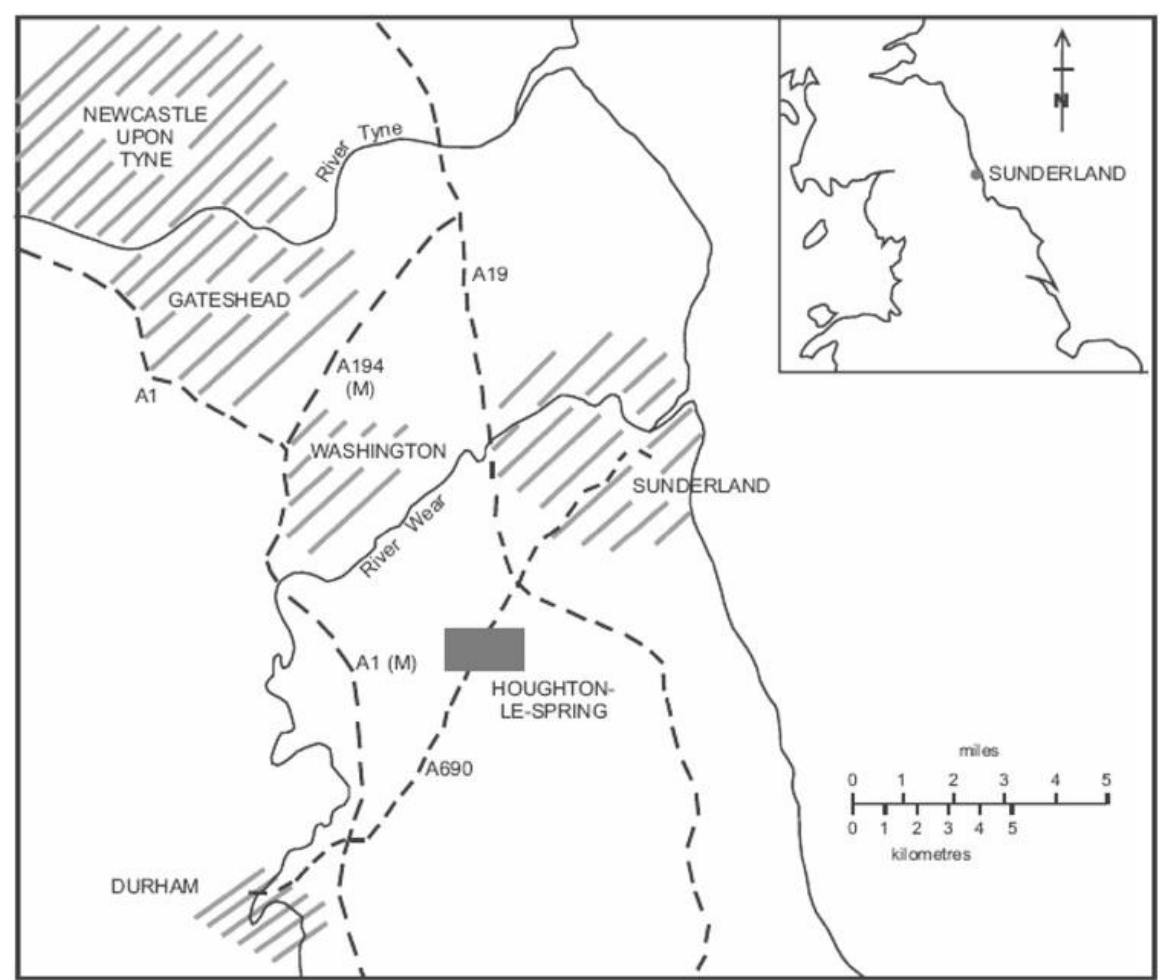

Fig. 2 Location map for study area (Young and Lawrence 2002)

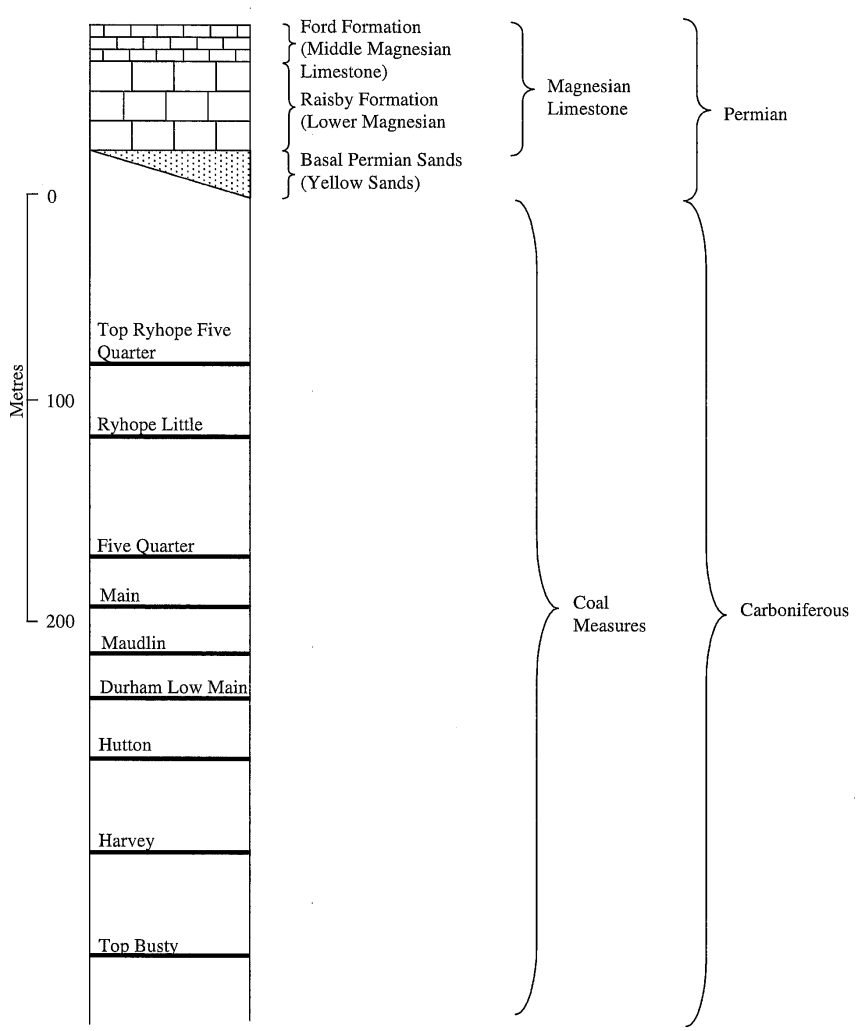

Fig. 3 Geological succession in the Houghton le Spring area (after Young and Culshaw 2001) 
Table 1 Details of the coal seams mined by partial extraction methods beneath the site

\begin{tabular}{|c|c|c|c|c|c|}
\hline \multirow[t]{2}{*}{ Seam name } & \multicolumn{2}{|c|}{$\begin{array}{l}\text { Dates worked } \\
\text { beneath site } \\
\text { (approx.) }\end{array}$} & \multirow[t]{2}{*}{$\begin{array}{l}\text { Elevation } \\
\text { (m AOD) }\end{array}$} & \multirow[t]{2}{*}{$\begin{array}{l}\text { Seam } \\
\text { thickness } \\
(\mathrm{m})\end{array}$} & \multirow[t]{2}{*}{$\begin{array}{l}\text { Extracted } \\
\text { thickness } \\
\text { (m) }\end{array}$} \\
\hline & From & To & & & \\
\hline Ryhope little & - & - & -78 & 0.7 & Not worked \\
\hline Five quarter & 1914 & 1947 & -107 & 1.0 & 0.6 \\
\hline Main & 1914 & 1948 & -174 & 1.9 & 1.1 \\
\hline Maudlin & 1914 & 1947 & -193 & 1.5 & 0.9 \\
\hline Low main & 1914 & 1961 & -214 & 1.4 & 0.8 \\
\hline Hutton & 1827 & 1900 & -242 & 2.3 & 1.4 \\
\hline
\end{tabular}

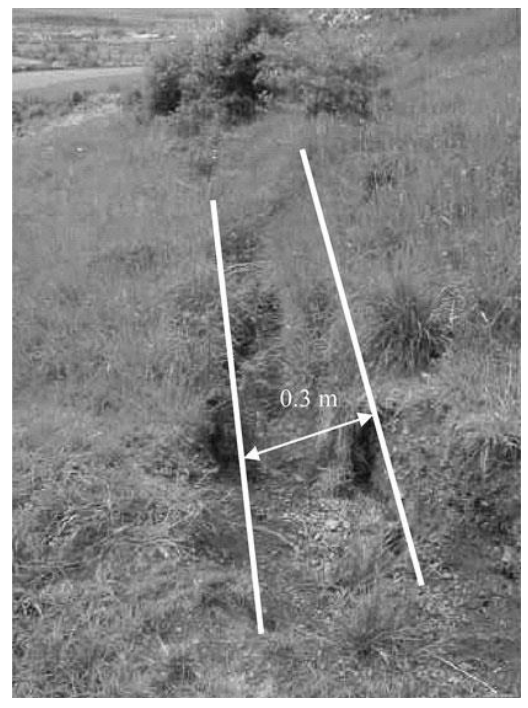

Fig. 4 Ground collapse above a fissure, Houghton-le-Spring, UK

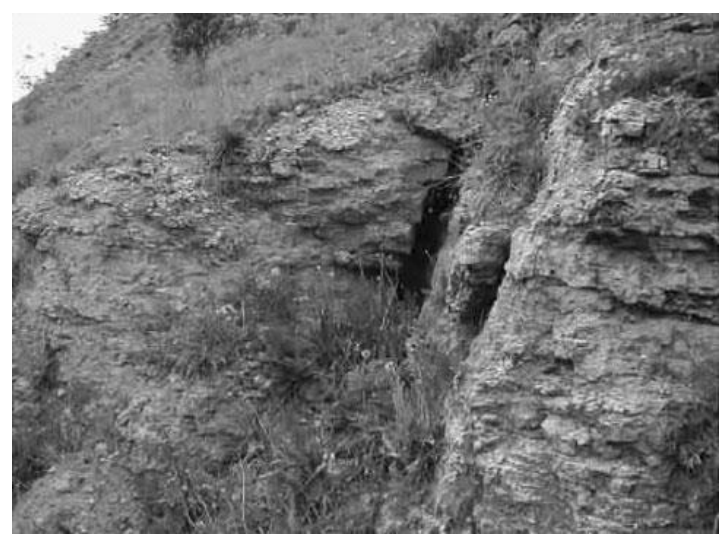

Fig. 5 Open fissure in western side of the A690 cutting, Houghton-le-Spring, UK 


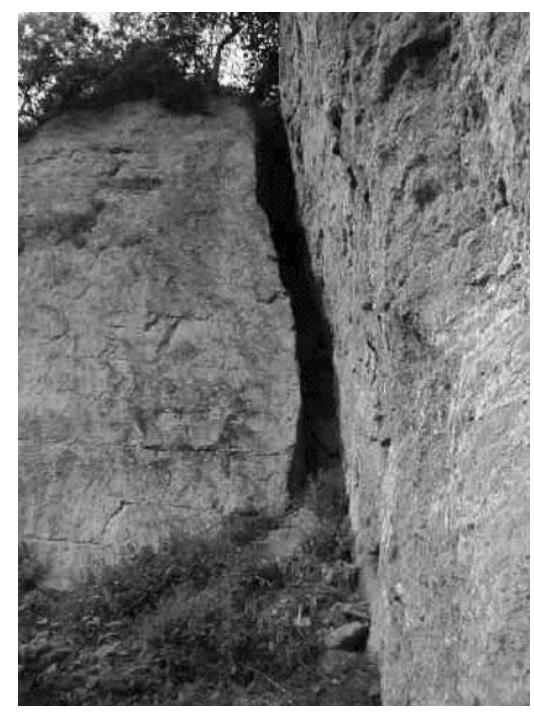

Fig. 6 Open fissure in the Old Cemetery, adjacent to A690, Houghton-le-Spring, UK

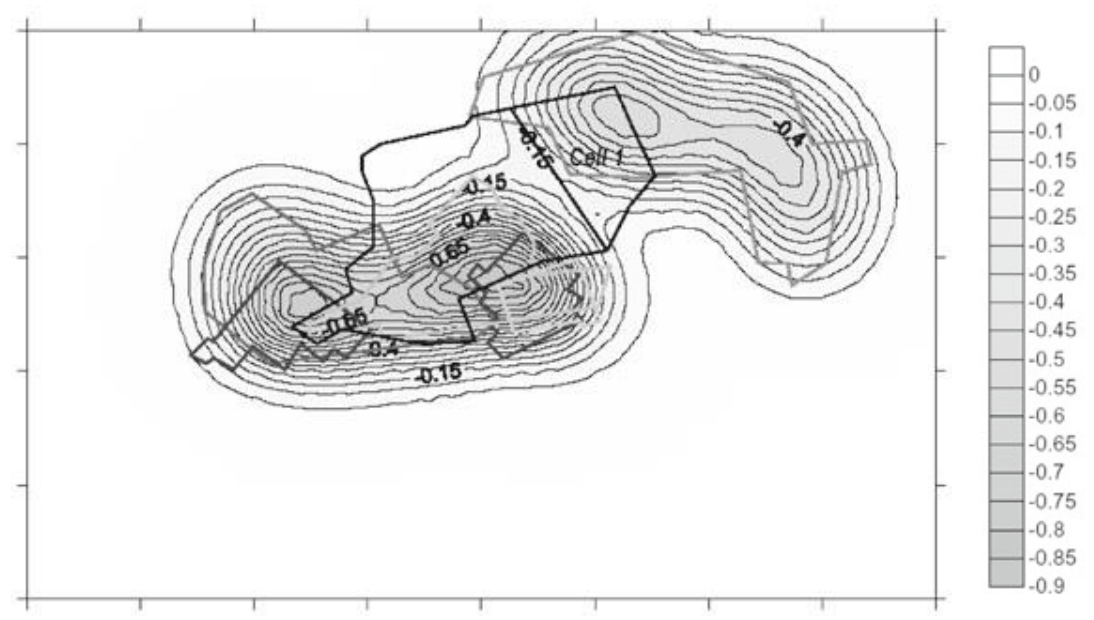

Fig. 7 Subsidence contours above all the mined seams (note the outlines represent the mined areas within individual seams beneath the site; all numeric values in metres)

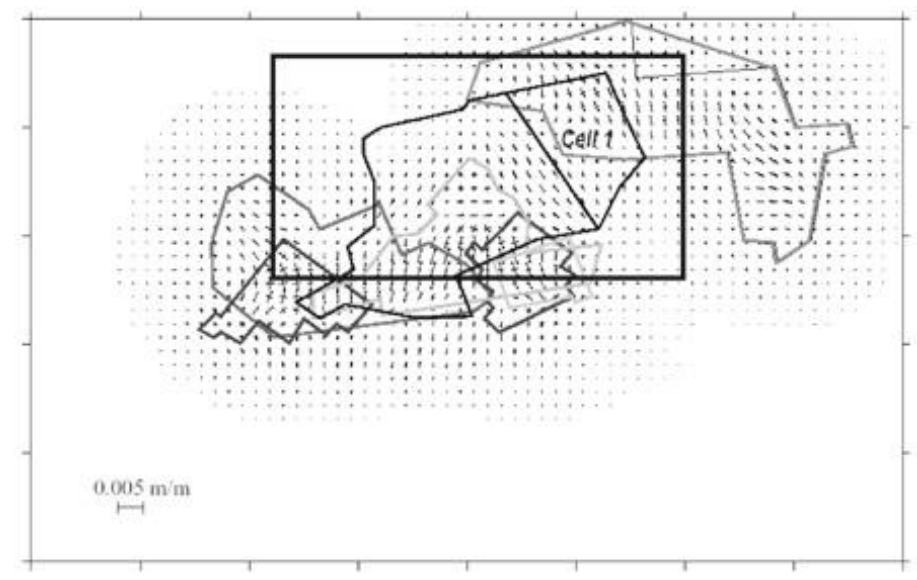

Fig. 8 Surface strain vectors above all the mined seams (vertical and horizontal scales in metres) 


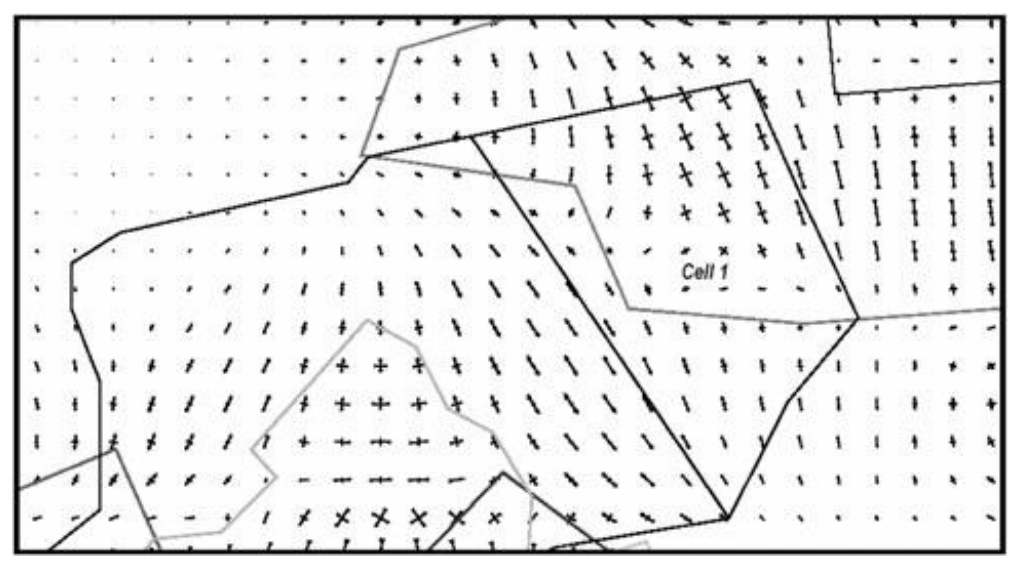

Fig. 9 Surface strain vectors above Cell 1 (not to scale)

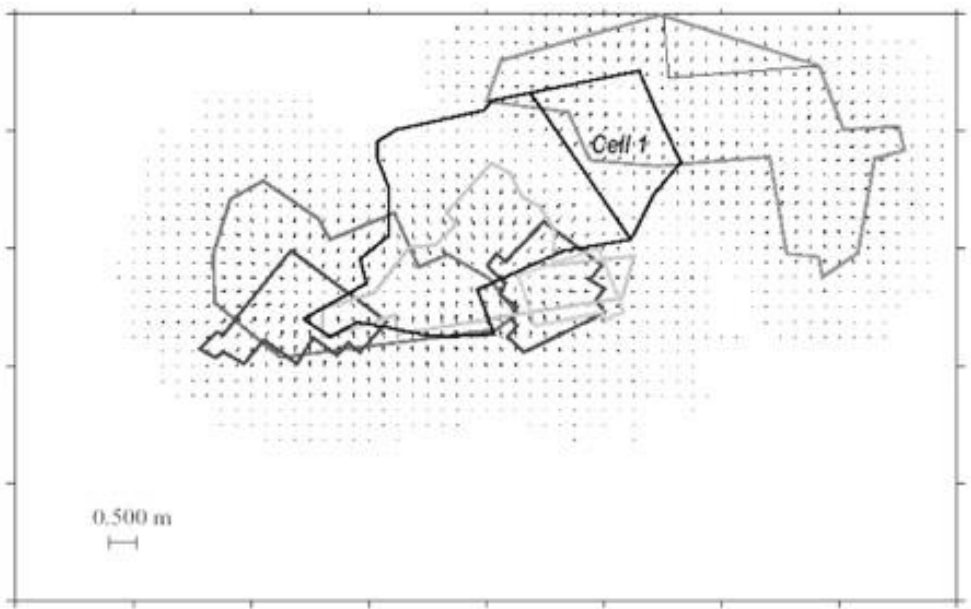

Fig. 10 Surface displacement vectors above all the seams (vertical and horizontal scales in metres)
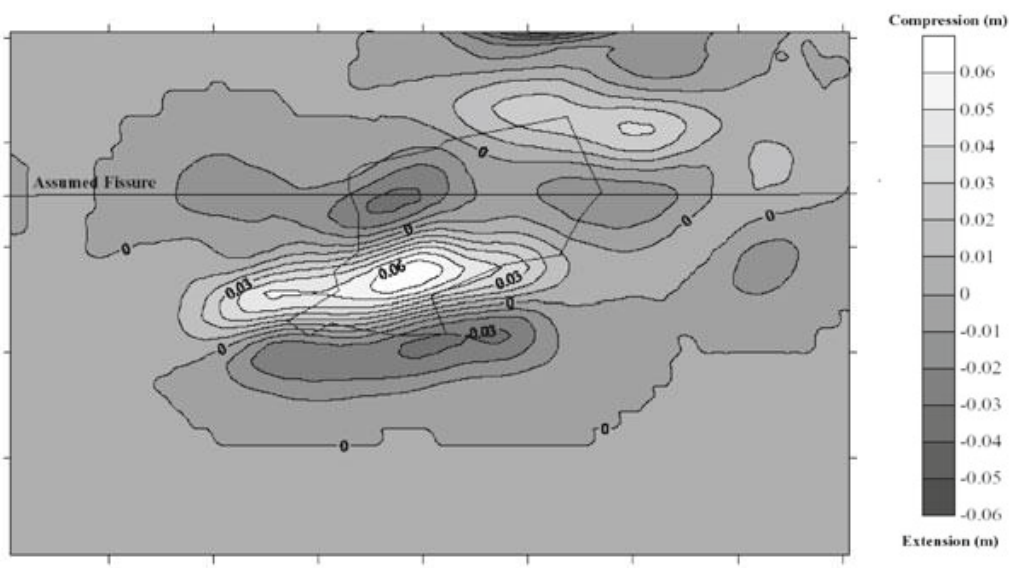

Fig. 11 Horizontal aperture displacement across east-west aligned fissures (vertical and horizontal scales in metres) 
Table 2 Material properties assumed in the numerical model

\begin{tabular}{|c|c|c|c|c|c|c|}
\hline Material & Thickness (m) & Density $(\mathrm{kg} / \mathrm{m} 3)$ & Young's modulus (MPa) & Poisson's ratio & Friction angle $\left({ }^{\circ}\right)$ & Cohesion(kPa) \\
\hline Waste & 30 & 1,200 & - & - & - & - \\
\hline Sand & 1 & 2,000 & 21 & 0.3 & 30 & 0 \\
\hline Geomembrane & 0.002 & - & 180 & 0.3 & 15 & - \\
\hline Clay & 1 & 2,000 & 16 & 0.3 & 27 & 5 \\
\hline Engineered fill & 1 & 2,300 & 150 & 0.4 & 45 & 0 \\
\hline Limestone & 7 & 2,500 & 40,000 & 0.3 & - & - \\
\hline
\end{tabular}

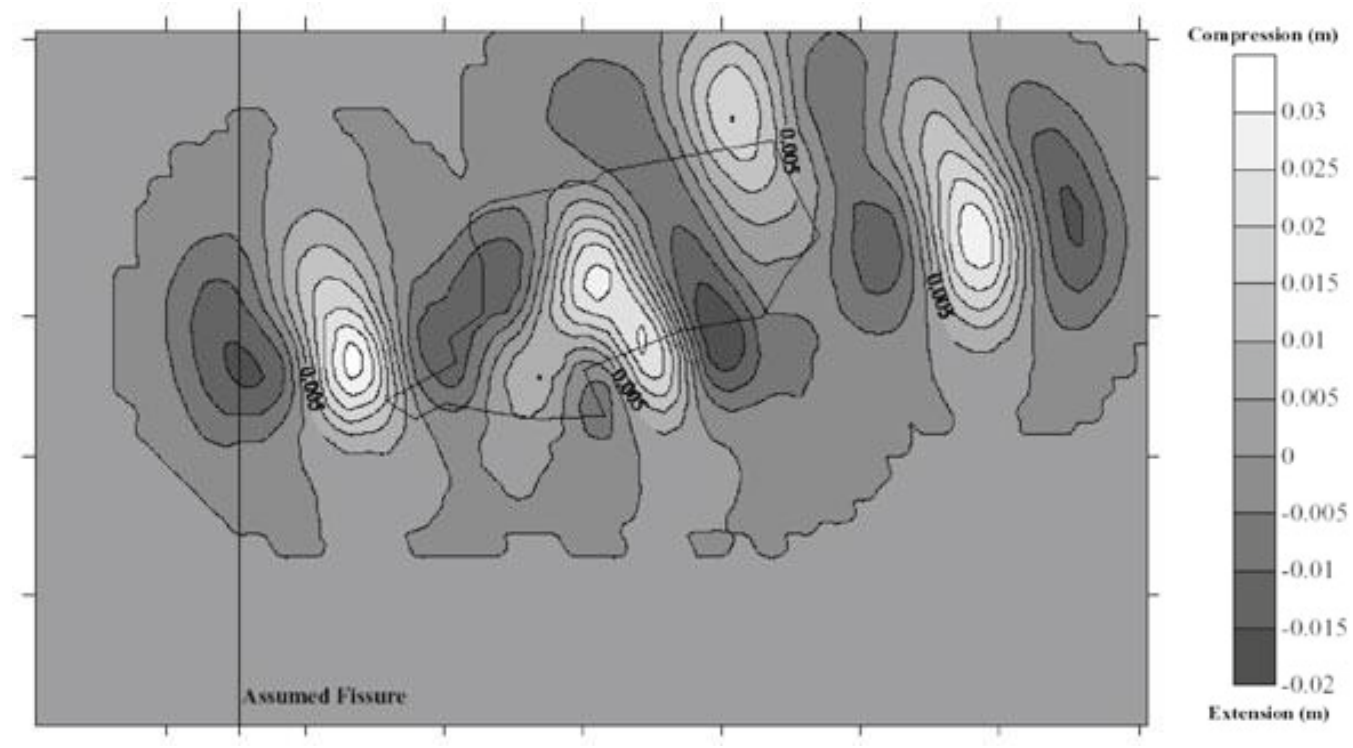

Fig. 12 Horizontal aperture displacement across north-south aligned fissures (vertical and horizontal scales in metres)

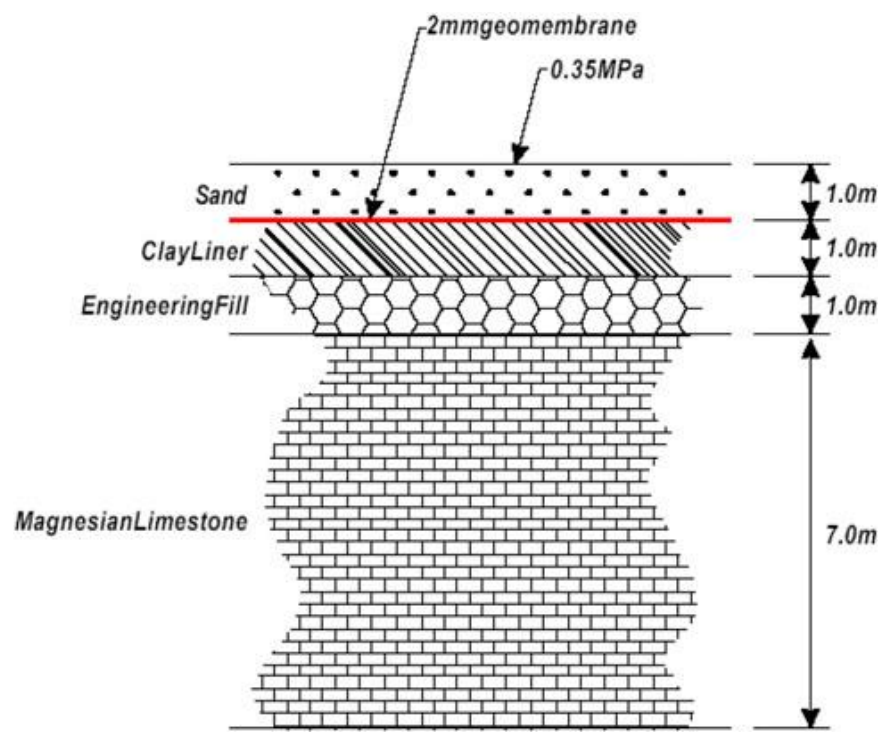

Fig. 13 Numerical model configuration 


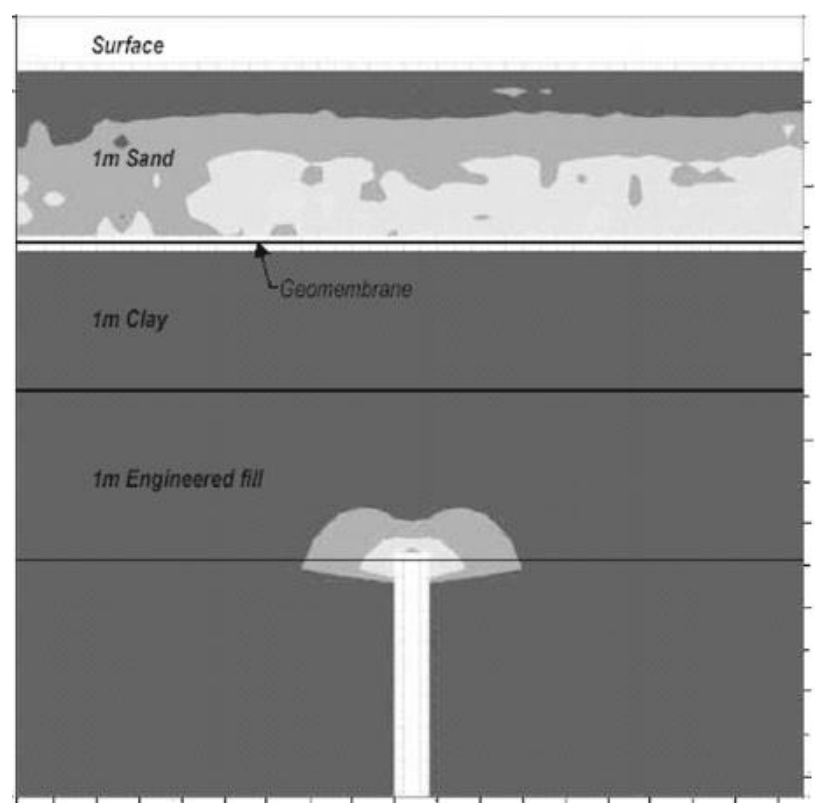

Fig. 14 Shear strain contours above a 0.10-m-wide fissure in the Magnesian Limestone (vertical and horizontal scales in metres)

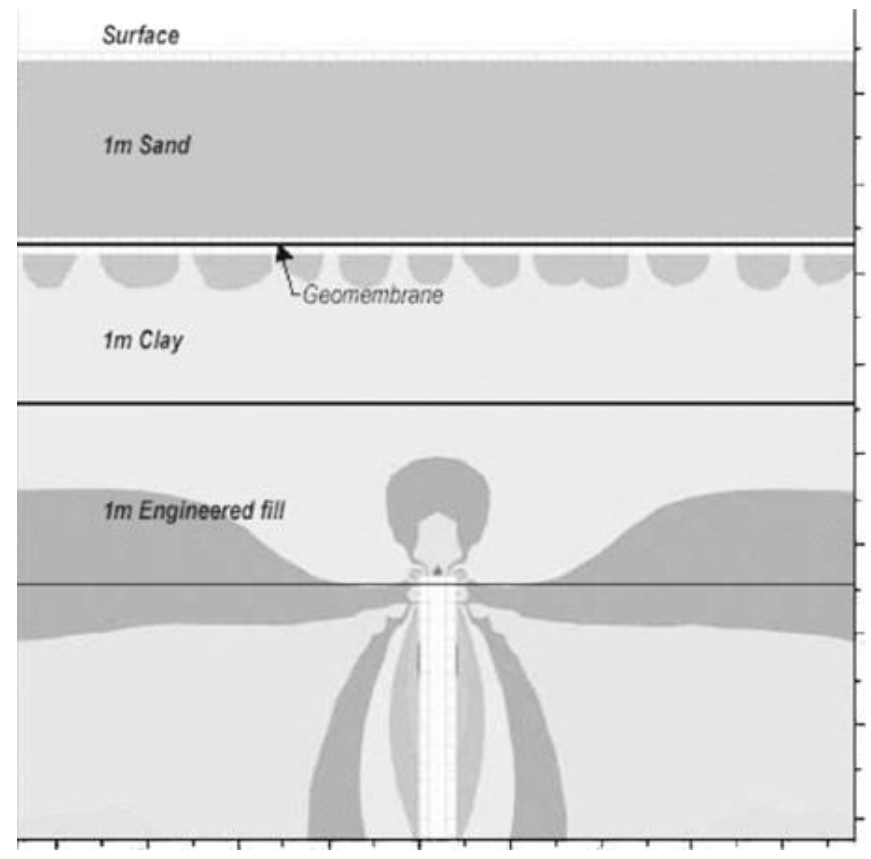

Fig. 15 Vertical stress contours above $0.10 \mathrm{~m}$ wide fissure (vertical and vertical and horizontal scales in metres) 